\title{
回分式活性污泥法における脱リン特性
}

岡 田 光 正* 上 野 泰 功*
林 奇 剛*

\section{Population Dynamics of Bacteria for Phosphorus Removal in Sequencing Batch Reactor (SBR) Activated Sludge Processes}

\author{
Mitsumasa OKADA*, Yasunori UENO*, \\ Chi-Kang LIN* and Akihiko MURAKAMI*
}

* Department of Chemical Engineering, Tokyo University and Technology, 2-24-16, Nakamachi, Koganei-shi, Tokyo 184 Japan

\begin{abstract}
Laboratory-scale sequencing batch reator (SBR) activated sludge processes were operated using synhtetic wastewater to clarify the effects of solids retention time (SRT) and organic substrates on the accumulation of bio-P-bacteria.

The accumulation of bio-P-bacteria could be enhanced by large fluctuation in concentration of organic substances in the reactor by filling in a short period of time under anaerobic condition. However, the accumulation could not be enhanced in the reactor operated with SRT less than $25 \mathrm{~d}$. The specific growth rate $(\mu)$ of bio-P-bacteria were estimated to range from 0.033 $\mathrm{d}^{-1}$ to $0.035 \mathrm{~d}^{-1}$ in the SBR activated sludge processes fed with glucose and polypeptone (GP). Therefore, large solids retention time (SRT) would be necessary for the accumulation of bio-P-bacteria. Volatile fatty acids (VFA), such as sodium acetate (A), enhanced in-situ specific growth rate of bio-P-bacteria and seemed to be effective than other organic substates (ex: GP) for the accumulation of bio-P-bacteria in activated sludge ecosystem.
\end{abstract}

Key words : phosphorus removal, bio-P-bacteria, specific growth rate, solids retention time, volatile fatty acids

\section{1.はじめに}

湖沼や内湾等の閉鎖性水域の人為的富栄養化を防止 するため，排水からのリンの除去が求められている。 リンの除去法には, 凝集剤添加や晶析等の化学的な方 法と嫌気反応と好気反応を組み合わせた生物学的な方 法とがある。しかし，化学的な方法はランニングコス 卜，污泥生成量の増加等の問題があるため, 生物学的 脱リン法が注目され，運転方法やリン除去機構に関す

\footnotetext{
る検討が行われてきた。

運転方法に関しては,
}

（1）流入水の有機物濃度は, BOD として少なくとも50 $\mathrm{mg} \cdot l^{-1}$ であること市,,

（2）嫌気槽では DO が検出されないことが望ましく， 好気槽ではおおむね $2 \mathrm{mg} \cdot \mathrm{l}^{-1}$ 以上あれば十分である こと尚,4)

（3）安定なリンの過剩摂取には $\mathrm{pH} 7$ ～8が望ましい こと卢,6)，等の多くの報告がある。

* 東京農工大学工学部物質生物工学科 $\overline{\mathrm{T}} 184$ 東京都小金井市中町 2-24-16 
また，リン除去機構に関しても，

（1）嫌気反応に扔いて，脱りンを行う活性污泥微生物 群が菌体内のポリリン酸を分解しながら ATP 生産を 行い,この ATP を利用することによって, 細胞外有機 物を PHB，グリコーゲンとして貯蔵する77,8),

(2) 嫌気反応でのリン放出は, ATP 利用の際の $\mathrm{ATP}+\mathrm{H}_{2} \mathrm{O} \rightarrow \mathrm{ADP}+\mathrm{H}_{3} \mathrm{PO}_{4}$ の加水分解に伴って起 こる,

（3）このように有機物を細胞内に貯蔵した脱りンを行 う活性污泥微生物群は，好気反応において呼吸代謝を 行い, 貯蔵した有機物を酸化してATP を生産しこの 時 $\mathrm{ADP}+\mathrm{H}_{3} \mathrm{PO}_{4} \rightarrow \mathrm{ATP}+\mathrm{H}_{2} \mathrm{O}$ のようにリンを取り 込む,

（4）嫌気反応での有機物摂取に対しては脱リンを行う 活性污泥微生物群が有利となるため, 嫌気反応を設け ることにより脱りンを行う活性污泥微生物群が優占と なる，

等の報告がされてきた ${ }^{10)}$ 。

同時に，生物学的脱りンを担う微生物相に関する検 討も行われ, Fuhs 他の報告以来, 生物学的脱リン施設 に Acinetobacter 属が多く存在していることが指摘さ れている7)。しかし，その生理学的特性に関する検討か ら,

(1) Acinetobacter calcoaceticus は, 嫌気条件下で酢酸 の摂取を行わない9，

（2）Acinetobacter 属は沈降性が悪く，系から washoutする ${ }^{10)}$,

ことが明らかとなっている。この事実は，脱りンを行 う活性污泥微生物群の知見と矛盾するものである。ま た,Acinetobacter 属やその他の細菌の純粋培養による 研究では，嫌気反応でのリンの放出と有機物捸取，そ の後の好気反応でのリンの過剩摂取現象は十分に説明 されていない11)

そこで, 本研究では, Acinetobacter 属のような単一

Table 1 Composition of the synthetic wastewater

\begin{tabular}{|l|c|}
\hline \multicolumn{1}{|c|}{ Reagent } & $\begin{array}{c}\text { Concentration } \\
{\left[\mathrm{mg} \cdot l^{-1}\right]}\end{array}$ \\
\hline $\mathrm{K}_{2} \mathrm{HPO}_{4}$ & 21.75 \\
$\mathrm{KH}_{2} \mathrm{PO}_{4}$ & 8.5 \\
$\mathrm{NaHPO}_{4} \cdot 12 \mathrm{H}_{2} \mathrm{O}$ & 1.7 \\
$\mathrm{NH}_{4} \mathrm{Cl}$ & 44.6 \\
$\mathrm{MgSO}_{4} \cdot 7 \mathrm{H}_{2} \mathrm{O}$ & 2.25 \\
$\mathrm{NaHCO}_{3}$ & 800 \\
$\mathrm{FeCl}_{3} \cdot 6 \mathrm{H}_{2} \mathrm{O}$ & 0.025 \\
$\left(\mathrm{NH}_{4}\right)_{2} \mathrm{SO}_{4}$ & 272.5 \\
$\mathrm{~K}_{2} \mathrm{HPO}_{4}$ & 22.5 \\
\hline
\end{tabular}

の細菌に着目することを避け，活性污泥中の脱リン能 力を持つ微生物群集全体 (以後脱リン微生物と総称す る）を評価する必要があると考えた。そして，回分式 活性污泥法を用いて，その排水流入方法，嫌気時間， SRT (污泥滞留時間) 等の運転方法やグルコース+ポ リペプトンの他に酢酸ナトリウム等の基質が活性污泥 の脱リン能力の獲得，すなわち脱リンを行う微生物群 集の集積にどのように影響するかに検討を加えた。

\section{2. 実験方法}

\section{1 処理特性}

\section{1 .1 人工排水}

本研究に用いた人工排水の栄養塩類組成を Table 1 に示す。炭素源としてはグルコース十ポリペプトン （1：1）を用いたが，A-2 の RUN（運転サイクルは $\mathrm{L}-2$ と同じ）では酢酸ナトリウムを用いた（TOC= $\left.320 \mathrm{mg} \cdot l^{-1}\right)$ ○リンは最大脱リン能力を明らかにするた めにやや過剩 $\left(\mathrm{PO}_{4}-\mathrm{P}=15 \mathrm{mg} \cdot l^{-1}\right)$ に加えた。実験に 使用する際には，まず Table 1 の栄養塩類と炭素源 $\left(\mathrm{TOC}=320 \mathrm{mg} \cdot l^{-1}\right)$ の 5 倍濃度に相当する人工排水

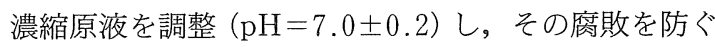

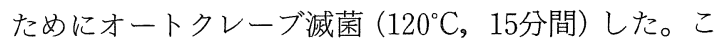
れを水道水によって 5 倍に希釈しながら活性污泥装置 に供給した。

\section{1 .2 実験装置および操作}

本研究に用いた回分式活性污泥装置は，透明塩ビ製 の角型反応槽 (有効容量 $5 l$ ) である。嫌気時間中は緩 速攪拌 (120r.p.m.)，好気時間中はディフューザーを用 いた曝気により混合した。人工排水の供給，嫌気・好 気時間の制御, 処理水の放流, 污泥の引き抜き等はシー ケンスコントローラ (富士電気 FUJILOG $-\mu \mathrm{P})$ で行っ た。人工排水は小型電磁弁（高砂ピンチバルブ

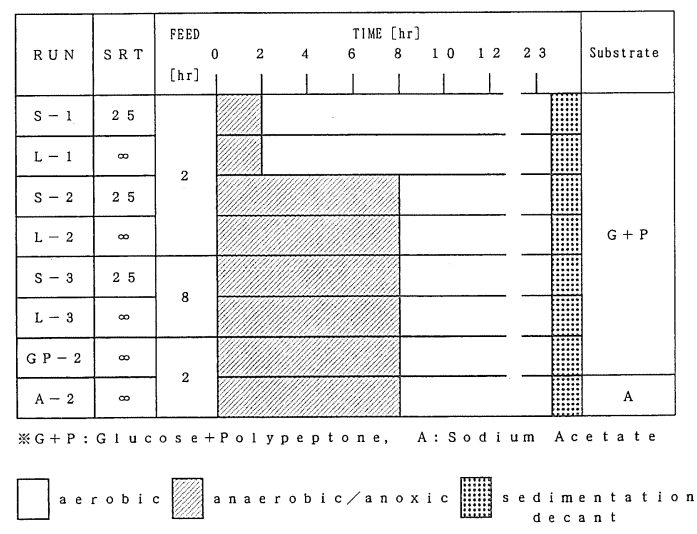

Fig. 1 Operation schedule 
PK3-05)の開閉によって供給し，供給時間はシーケン スコントローラで調整した ${ }^{12)}$ 。装置全体は $20 \pm 1{ }^{\circ} \mathrm{C} の$ 恒温室に設置した。

ここで検討した基質および運転方法を Fig.1に示 す。排水の流入開始から上澄水の放流終了までを 1 サ イクルとし，1サイクル24時間で繰り返した。污泥の 滞留時間（SRT）は25日および污泥を引き抜かない場 合とした。排水は各サイクルの初期に供給し，供給時 間は 2 時間または 8 時間とした。嫌気時間もサイクル 初期に 2 時間もしくは 8 時間とした。排水の供給は嫌 気時間中に行い，好気時間終了後30分間污泥を沈降さ せ，上澄水を放流した(10分間)。なお，全実験を通じ BOD 負荷は $0.36 \mathrm{~kg}-\mathrm{BOD} \cdot \mathrm{m}^{-3} \cdot \mathrm{d}^{-1}$ とした。したがっ て $5 l$ の反応槽に対し， 1 サイクル当り $2.5 l$ の排水を 供給し，処理後同じ量を放流した。

\section{1 .3 植 種}

$\mathrm{L}-1 \sim 3, \mathrm{~S}-1 \sim 3$ の RUN では S 下水処理場の 返送污泥をグルコース十ポリペプトンを炭素源とする 人工排水で 2 週間培養した。前培養は 1 サイクル 24 時 間, 全好気の Fill-and-draw 方式で行った後, いずれの 反応槽にも初期の MLSS 濃度が $5,000 \mathrm{mg} \cdot l^{-1}$ となる ように投入した。また $\mathrm{A}-2$ および $\mathrm{GP}-2$ では同じ 返送污泥を前培養なしに初期の MLSS 濃度が3,000 $\mathrm{mg} \cdot l^{-1}$ となるように投入した。

\section{2 脱リン活性の測定}

すでに述べたように，活性污泥中の脱リン能力を微 生物群（以後脱りン微生物とよぶ）は，単一種である 保証がない ${ }^{14)}$ 。このためその菌数を直接測定すること は試みず，運転方法に関する検討では脱リン微生物量 を脱りン活性，すなわち嫌気時間における単位污泥量 当りのリン放出量，もしくは好気時間におけるリン取 り込み量により評価することを試みた。その方法は下 記の通りである。

\section{2 .1 污泥の前処理}

回分反応の沈殿時間直前に活性污泥混合液を採取 し，残存する有機物，リン等の影響を排除するため， 2,000r.p.m.で 2 分間，2 回遠心分離によって洗浄し た。洗浄液としては炭素源を除いた人工排水を用いた。

\section{2 .2 操 作}

洗浄した活性污泥を炭素源を除いた人工排水で MLSS として $2,000 \mathrm{mg} \cdot l^{-1}$ に調整した。これを約 30 分 間曝気した後, $500 \mathrm{~m} l$ 三角フラスコに入れ，窒素ガス $\left(2 \mathrm{~kg}^{-} \mathrm{cm}^{-2}\right)$ で 5 分間程度置換してフラスコ内の溶 存酸素濃度を $0.2 \mathrm{mg} \cdot l^{-1}$ 以下にした。これに, 人工排水 に用いた炭素源と同一のグルコース+ポリペプトンま たは酢酸ナトリウムを $\mathrm{TOC}=500 \mathrm{mg} \cdot l^{-1}$ となるよう に添加し，密封後，緩速攪汼 (120r.p.m.) で6 時間嫌
気培養した。6 時間後, リン $\left(\mathrm{PO}_{4}-\mathrm{P}\right)$ を $20 \mathrm{mg} \cdot l^{-1}$ 添 加し, 小型エアーポンプにより曝気しながら 8 時間好 気培養した。この間適宜に活性污泥混合液をサンプリ ングし，その沪液(グラスファイバー沪紙, Whatman GF/C で沪過)のリン酸態リン濃度を測定した。嫌気状 態におけるリン放出活性は $0 \sim 6$ 時間の単位 MLSS 当りのリン放出量 $\left(\mathrm{mg}-\mathrm{P} \cdot \mathrm{mg}^{-1}-\mathrm{MLSS}\right)$ とし, 好気状 態におけるリン取み込み活性は $6 \sim 14$ 時間の単位 MLSSあたりのリン取り込み量 $\left(\mathrm{mg}-\mathrm{P} \cdot \mathrm{mg}^{-1}\right.$ -MLSS) とした。

\section{3 分析方法}

処理水の DOC はグラスファイバー沪紙 (Whatman GF/C) で沪過後全有機炭素分析計（島津制作所 TOC -500型）で，またりン酸態リンはモリブデン青法で測 定した ${ }^{15)}$ 。MLSS の測定は下水試験方法に従った ${ }^{16)}$ 。

\section{3. 実験結果と考察}

\section{1 活性污泥装置の脱リン性能}

Fig. 2 亿運転開始 20 日目以降の処理水中のリン酸態 リン濃度の経時的変化を示す。嫌気時間が 8 時間，供 給時間が 2 時間で污泥引き抜きを行わない $L-2$ は, 約60日目以降処理水中のリン濃度が低下し，いわゆる 生物学的脱リンが認められた。また嫌気時間，污泥引 き抜きは同様であるが，供給時間が 8 時間と長い $\mathrm{L}$ - 3 においてやや遅れて約 80 日目以降処理水中のリン 濃度が低下した。しかし，SRTが25日である S-1に おいては100日以上経過しても, 処理水中のリン濃度の 低下が認められなかった。また，SRT が25日である S - $2, \mathrm{~S}-3$, ならびに污泥引き抜きは行わないが嫌気 時間を 2 時間と短くした $\mathrm{L}-1$ においても(図示せず) S- 1 と同様に処理水中のリン濃度は低下しなかっ た。これはリンの放出に必要な時間が 2 時間では不十

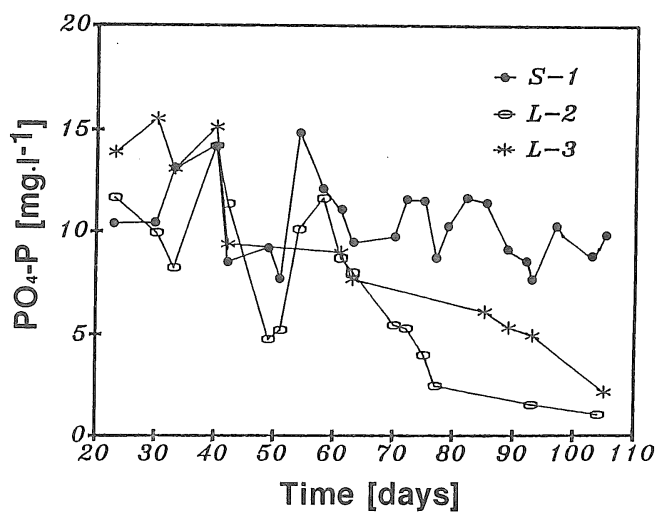

Fig. 2 Decrease in ortho-phosphate concentration in effluents 
分であったことによると思われる（Fig.4 参照，後 述) ${ }^{17)}$ 。したがって, 生物学的脱リン能力を持つ活性污 泥を得るには，污泥の滞留時間を長く，また十分な嫌 気時間をとることが必要であると考えられる。

Fig. 3 に S-1 およびL一2 における MLSSの経 時的変化を示す。SRT が25日である S-1では MLSS が初期の $5,000 \mathrm{mg} \cdot l^{-1}$ から徐々に低下し，2,000 〜3,000 mg・l $l^{-1}$ で安定した。SRTが25日である S $-2, S-3$ も同様であった(図示せず)。しかし, L-2 では污泥を引き抜かないために MLSS が次第に増加 し, 約 $6,000 \mathrm{mg} \cdot l^{-1}$ と高い值で安定した。 $\mathrm{L}-1, \mathrm{~L}-3$ も同様であった(図示せず)。すなわち，污泥引き抜き を行わないLの系列では，SRTが25日である S の系 列と比較して MLSS が約 $2 \sim 3$ 倍となった。

Fig. 4 は L-1，L-2，L-3 の14週間（約100日） 目に測定したリン酸態リン濃度の 1 サイクルにおける 経時的変化を示す。嫌気時間が 2 時間であり，リン濃 度が低下しなかった L一 1 は，14週間経過しても嫌気 時間におけるリン放出と好気時間におけるリン取り込 みは見られなかった。しかし，嫌気時間が 8 時間であ

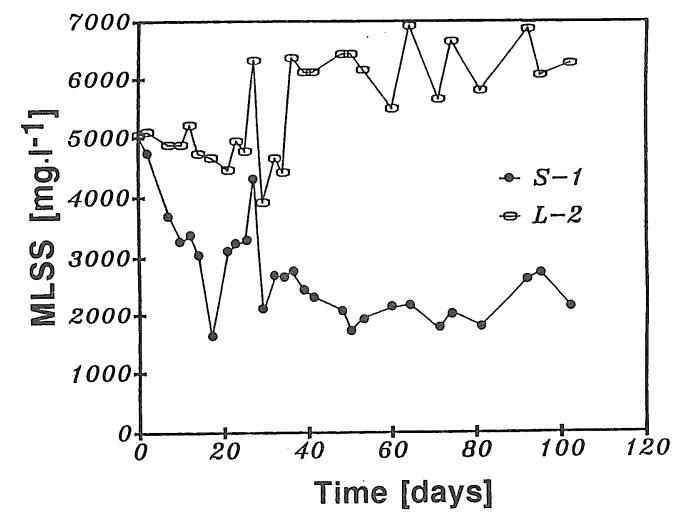

Fig. 3 MLSS concentrations as affected by solids retention time

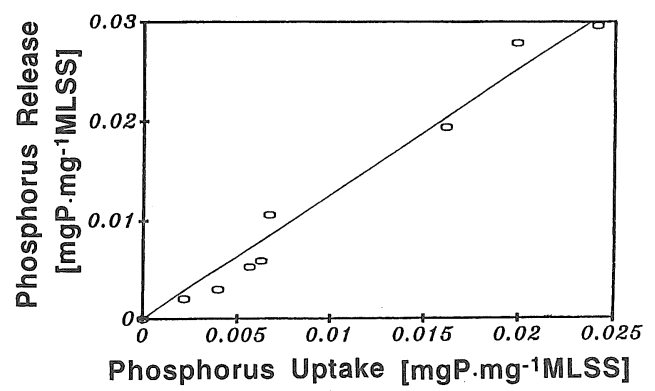

Fig. 5 Relationship between phosphorus release and phosphorus uptake activities in RUN L-2
る $L-2, L-3$ は，嫌気時間におけるリン放出と好気 時間における過剰摂取が認められた。したがって，処 理水中のリン濃度の低下は生物学的脱リンによるもの と推定された。

\section{2 脱リン活性と脱リン微生物の集積}

Fig.5 亿嫌気時間での活性污泥のリン放出活性と好 気時間でのリン取り込み活性の関係を示す。図から明 らかなように，両者がほぼ比例関係にあったため，以 降嫌気時間におけるリン放出活性によって脱りン活性 を評価した。

Fig. 6 に脱リン活性の経時的変化を示す。生物学的 脱リンが認められた $\mathrm{L}-2, \mathrm{~L}-3$ は, 50 日以降脱リン 活性が上昇した。しかし，生物学的脱リンが認められ なかったS－1においては, 100日以上経過しても脱り ン活性が上昇しなかった。これらの事実より，L-2， $\mathrm{L}-3$ に扔ける処理水中のリン濃度の低下は，十分な 嫌気時間を取ることにより（S-1 との比較），また SRT を長く保つことによって $(\mathrm{S}-2, \mathrm{~S}-3$ との比 較)，活性污泥の脱りン活性が増加したためといえよ う。

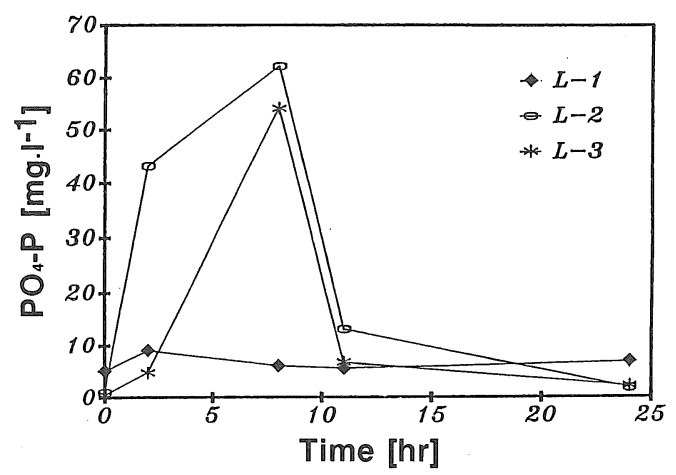

Fig. 4 Profiles of orhto-phosphste concentrations in a cycle of opertion

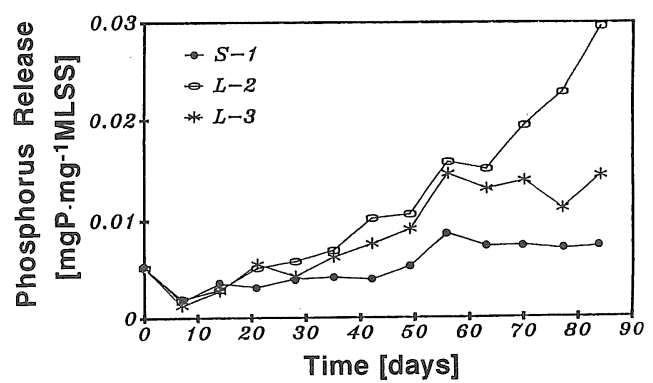

Fig. 6 Increase in phosphorus release activities 
これまでの研究において, Acinetobacter 属の最大比

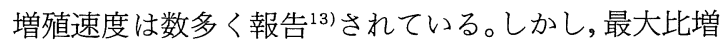
殖速度は実際の活性污泥よりはるかに高い基質濃度で 得られている。またすでに述べたように Acinetobacter 属が活性污泥の脱リン能力の大部分を担っている保証 はない。したがって, その最大比増殖速度から脱リン 微生物の集積過程を論ずることは困難である。ここで は,脱リン活性が脱リン微生物量に比例すると仮定し, Fig. 6 の結果をもとに脱りン微生物の比増殖速度 $\mu_{\mathrm{p}}$ を以下の方法で推定した。

まず， $\nu_{\mathrm{p}}$ を脱リン活性 $\left(\mathrm{mg}-\mathrm{P} \cdot \mathrm{mg}^{-1} \mathrm{MLSS}\right) ， X$ を 総微生物濃度 $(\mathrm{MLSS})\left(\mathrm{mg} \cdot \mathrm{l}^{-1}\right), X_{p}$ を脱りン微生物 濃度 $\left(\mathrm{mg} \cdot l^{-1}\right), a$ を単位脱りン微生物が放出し得るリ ン量 $\left(\mathrm{mgP} \cdot \mathrm{mg}^{-1} \mathrm{X}_{\mathrm{p}}\right)$ とすると, 脱リン微生物活性は 次式で定義される。

$$
\nu_{\mathrm{p}}=a \cdot \frac{X_{p}}{X}
$$

また, 脱りン微生物の比増殖速度 $\left(\mathrm{d}^{-1}\right)$ を $\mu_{\mathrm{P}}$, 微生物 全体 (MLSS) の比増殖速度を $\mu_{x}$, 放流に伴う装置内 活性污泥の比流出速度 $\left(\mathrm{d}^{-1}\right)$ を $b$ とすると次式が成立 する。

$$
\begin{aligned}
& \frac{1}{X_{p}} \cdot \frac{\mathrm{d} X_{p}}{\mathrm{~d} t}=\mu_{p}-b \\
& \frac{1}{X} \cdot \frac{\mathrm{d} X}{\mathrm{~d} t}=\mu_{x}-b
\end{aligned}
$$

(1)式で $a$ 一定と仮定すると脱リン活性の増加速度 は次式で表わされる。

$$
\frac{\mathrm{d} \nu_{p}}{\mathrm{~d} t}=\frac{a}{X} \cdot \frac{\mathrm{d} X_{p}}{\mathrm{~d} t}-\frac{\nu_{p}}{X} \cdot \frac{\mathrm{d} X}{\mathrm{~d} t}
$$

(2)，(3)，(4)式より次式が得られる。

$$
\frac{\mathrm{d} \nu_{\mathrm{p}}}{\mathrm{d} t}=\left(\mu_{\mathrm{p}}-\mu_{x}\right) \cdot \nu_{\mathrm{p}}
$$

よって, $\mathrm{t}=0$ の時の $\nu_{\mathrm{p}}$ を $\nu_{\mathrm{p} 0}$ とおくと(6)式が得られる。

$\ln \nu_{\mathrm{p}}=\left(\mu_{\mathrm{p}}-\mu_{x}\right) \mathrm{t}+\ln \nu_{\mathrm{p} 0}$

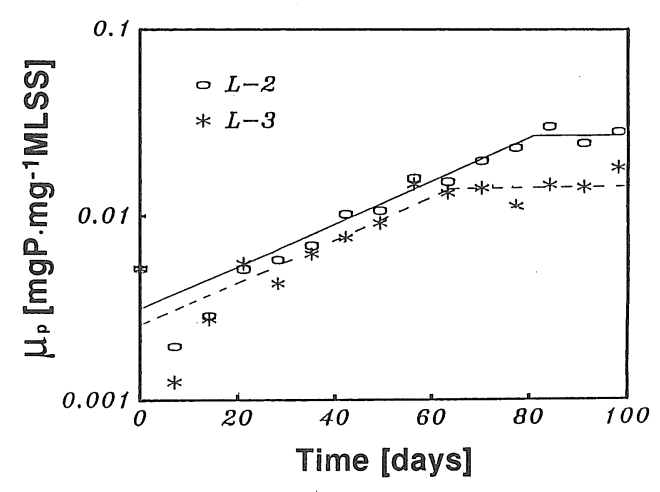

Fig. 7 In $\mu_{\mathrm{p}}$ vs time
(6)式をともに，時間 $\mathrm{t}$ に対して $\nu_{\mathrm{p}}$ をプロットした結果 を Fig. 7 に示す。Fig. 7 の傾きより L-2, L-3 の系 の $\mu_{\mathrm{p}}-\mu_{\mathrm{x}}$ は 20 日目から 60 日目の間で $0.028 \mathrm{~d}^{-1}$ と求め られた。また MLSS の経時的変化より $\mu_{x}$ を求めると $\mathrm{L}-2, \mathrm{~L}-3$ それぞれ0.005, $0.007 \mathrm{~d}^{-1}$ と求められた。 よって $\mathrm{L}-2, \mathrm{~L}-3$ の系の脱りン微生物の比増殖速 度 $\mu_{\mathrm{p}}$ はそれぞれ0.033，0.035 $\mathrm{d}^{-1}$ と推定された。

この值は Acinetobacter 属の報告された最大比増殖 速度と比較するとかなり小さい值である ${ }^{13)}$ 。しかし,ケ モスタット連続培養での $\mu_{\max }$ が $4.8 \mathrm{~d}^{-1}\left(20^{\circ} \mathrm{C}, \mathrm{pH}=\right.$ 8.2) である Acinetobacter 属が, 嫌気・好気を繰り返 したケモスタット連続培養によると $\mu_{\max }$ が $0.84 \mathrm{~d}^{-1}$ $\left(20^{\circ} \mathrm{C}, \mathrm{pH}=8.2 \sim 8.5\right.$, 嫌気槽内 $\mathrm{COD}=500 \mathrm{mg} \cdot l^{-1}$, 好気槽内 $\left.\mathrm{COD}=360 \mathrm{mg} \cdot l^{-1}\right)$ に低下するとの報告があ る ${ }^{18)}$ 。本研究に㧈いては温度, $\mathrm{pH}$ は, 同様な条件であ る。しかし, Fig. 8 亿示すように DOC 濃度が最大でも 約 $80 \mathrm{mg} \cdot l^{-1}$ と低いこと，また脱窒，硝化反応 (図示せ ず）も十分に行うべく，嫌気と好気反応時間を比較的 長く確保していることにより, 脱リン微生物の比増殖 速度 $\mu$ がかなり小さくなったものと考えられる。

なお，この值より比増殖速度 $\mu$ の逆数である SRT を求めると約 32 日であった。このため, SRT を 25 日と して運転した S の系列では脱リン微生物が wash-out し，脱リンが起こらなかったものと考元られる。一方， 污泥引き抜きを行わなかった $\mathrm{L}-2, \mathrm{~L}-3$ では脱り ン微生物が集積したものと考えられる。

\section{3 基質濃度および種類の影響}

Fig. 8 に L-2, L-3 の 1 サイクルでの DOC の経 時的変化を示す。供給時間が 2 時間である $\mathrm{L}-2$ は, 供 給時間が 8 時間である $\mathrm{L}-3$ と比較して，短時間で炭 素源が供給されるため, DOC の濃度変動が大きいこと がわかる。また, Fig. 7 より L-3 の脱りン微生物の増 殖が $\mathrm{L}-2$ のそれより早く飽和状態となっていること

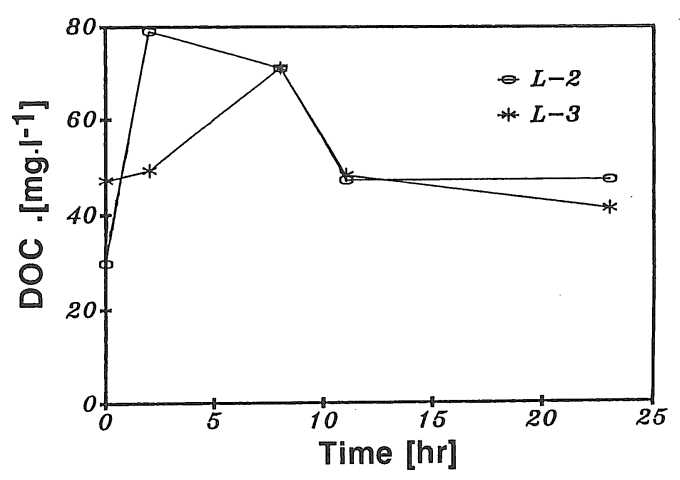

Fig. 8 Profiles DOC concentrations in a cycle of operation 


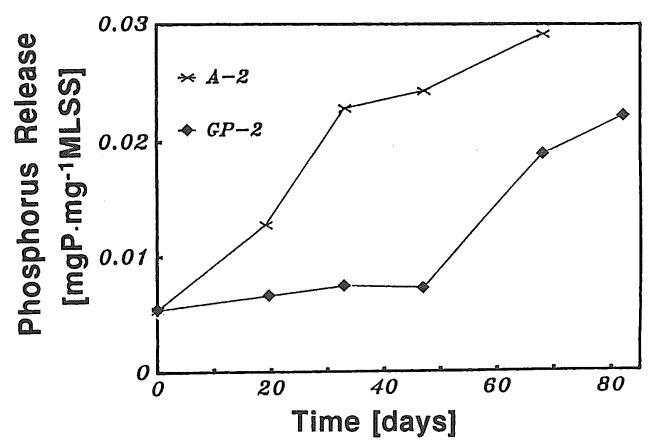

Fig. 9 Increase in phosphorus release activity から，有機物濃度変動が大きい方が活性污泥微生物生 態系内において脱リン微生物が優占となりやすいもの と推定された。

Fig.9は運転サイクルは L- 2 と同様であるが，基 質として酢酸ナトリウムを用いた場合 $(\mathrm{A}-2)$ とグル コース十ポリペプトンを用いた場合 $(\mathrm{GP}-2)$ の脱リ ン活性の経時的変化を示す。A-2 は $\mathrm{GP}-2$ に比較し て活性がすみやかに上昇した。これより，時間 $t$ に対 して $\nu_{\mathrm{p}}$ をプロットした結果を Fig. 10 に示す。

Fig. 10 の初期の傾きより $\mathrm{A}-2$ の $\mu_{\mathrm{p}}-\mu_{x}$ は0.043 $\mathrm{d}^{-1}$ となった。ここで，脱リン微生物活性が上昇した初 期40日間において A-2 の MLSS は約 $3,000 \mathrm{mg} ・ l^{-1}$ から約 $2,000 \mathrm{mg} \cdot l^{-1}$ に低下した (図示せず)。これは運 転開始初期において沈降性が不安定であったためであ る。その MLSS の経時的変化から $\mu_{x}$ を求めることは 困難であったものの， $\mu_{x}$ が 0 以下となることは考えに くい。よって $\mathrm{A}$ 系の脱リン微生物の比増殖速度 $\mu_{\mathrm{p}}$ は $0.043 \mathrm{~d}^{-1}$ 以上と考えられる。この值はグルコース＋ポ リペプトンを炭素源として求めた值 $(0.033 \sim 0.035$ $\left.\mathrm{d}^{-1}\right)$ より大きく，脱リン能力を持つ活性污泥微生物群 を集積するためには，炭素源として酢酸ナトリウムが グルコース十ポリペプトンより有効であると推定され た。

\section{4.おわりに}

回分式活性污泥法を用いて，活性污泥の脱リン活性 の向上と脱リン微生物の集積速度，ならびにそれに及 ぼす排水流入方法，嫌気時間，SRT(污泥の滞留時間） 等の運転方法の影響について検討した。活性污泥中に おける脱りン微生物の比增殖速度は，十分な嫌気時間 をとっても0.033〜0.035d $\mathrm{d}^{-1}$ (炭素源がグルコース +ポ リペプトン）と低いため，污泥の滞留時間を長く保つ ことが必要であった。また炭素源として酢酸ナトリウ ムがグルコーストポリペプトンより有効であった。

（原稿受理 1990年9月25日）

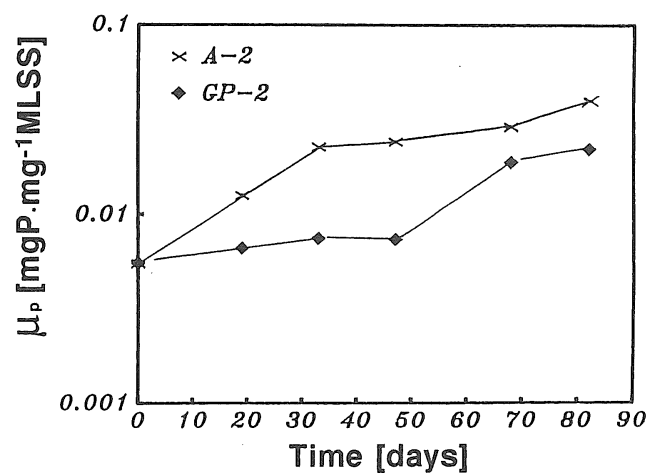

Fig. 10 Profiles of a growth curve

\section{引用 文 献}

1 ) 深瀬哲朗, 柴田雅秀, 宮地有正 (1982) 生物学的リン除去法 の下水への適応, 用水と廃水, 24, 1149-1156.

2 ) Kulaev, I.S. (1975) Biochemistry of inorganic polyphosphates, Rev. Physiol Biochem. Pharmacol., 73, 131-138.

3 ) Barnard, J.L. (1975) Biological phosphorus removal in the activated sludge process. review and proposals, Paper presented at the Johanesburg Branch of the Institute of W. P.C., July, 17.

4) 佐々木正一, 明賀春樹 (1982) Anaerobic-Oxic システムによ る生物学的脱リン法, 用水と廃水, 24, 1157-1161.

5 ) Broghton, W.H. (1971) Metabolic factors affecting enhanced phosphorusuptake by activated sludge, Appl. Michrobiol., 22, 571-578.

6 ）住吉盛幸, 森直道, 大竹康友（1982）嫌気・好気による生物 学的脱リン, 用水と廃水, 24, 1135-1140。

7 ) Fuhs, G.V. and Chen, M. (1975) Microbial basis of phosphate removal in the activated sludge process for the treatment of wastewater, Microbial Ecol., 2, 119-138.

8 ) 深瀬哲朗, 柴田雅秀, 宮地有正 (1982) 生物学的リン除去法 の機構に関する基礎的研究，水質污濁研究，22，309-317.

9 ) Ohtake, H., Takahashi, K., Tsuzuki Y. and Toda k. (1985) Uptake and release of phosphate by a pure culture of Acinetobacter calcoaceticus, Water Res., 19, 1587-1594.

10) Mino, T., Tsuzuki, Y. and Matsuo, T. (1986) Pure Culture Operation of Anaerobic Aerobic Process for Biological Phophorus Removal, 3rd German-Japanese Work-shop on Wastewater and Sludge Treatment, 34pp.

11) Cloete, T.E. and Steyn, P.L. (1988) The role of Acinetobacter as a phosphorus removing agent in activated sludge, Water Res., 22, 971-976.

12）岡田光正，須藤隆一，寺薗克博（1985）回分式活性污泥法に よる窒素，リン，及び有機物の同時除去に関する研究，水質污 濁研究，8，729-736。

13) Oliver, J.H. and Chang, C.H. (1987) Kinetics of growth and phosphate uptake in pure culture studies of Acinetobacter species, Biotechnol. Bioeng., 29, 819-831.

14）竹内準一他（1988）実施設における嫌気一好気運転下の活性 污泥細菌群の動態，用水と廃水，30，650-660。

15) U.S. EPA (1976) Method for Chemical Analysis of Water 
and Wastes, EPA-625/6-74-003a, 168-172.

16）日本下水道協会，下水試験方法（1984）。

17）岡田光正, 村上昭彦, 寺薗克博, 須藤隆一（1987）回分式活 性污泥法による高濃度排水の窒素，リン，有機物の同時除去， 水質污濁研究, 10, 741-748.
18) Tandoi, V., Beccari, M., Ramadori, R. and Annicchiarico, L.S. (1987) Acinetobacter sp. growth in alternate anaerobicaerobic conditions. "Biological Phosphate Removal From Wastewaters" (Ed. R. Ramadori), 305-308. Pergamon. 


\section{回分式活性污泥法における脱リン特性}

岡田 光正* 上野 泰功* 林 奇剛* 村上 昭彦*

* 東京農工大学工学部物質生物工学科

〈水質污濁研究 Vol.14 No.1(1991） pp.47～53〉

回分式活性污泥法を用い，その排水流入方法，嫌気時間，污泥滞留時間 (SRT) 等の運転方法やグルコース+ ポリペプトンの他に酶酸ナトリウム等の基質が活性污泥の脱リン能力の獲得，脱リン活性の向上，すなわち， 脱リンを行う微生物群集にどのように影響するかを検討をした。

活性污泥中おける脱リン微生物の比増殖速度は，十分な嫌気時間をとっても $0.033 \sim 0.035 \mathrm{~d}^{-1}$ (炭素源がグル コース+ポリペプトン) と低いため，污泥の滞留時間を長く保つことが必要であった。排水の供給時間が短い 方がよいことから，有機酸濃度変動が大きい方が活性污泥微生物生態系内において脱りン微生物が優占となり やすいと推定された。脱リン能力を持つ活性污泥微生物群を集積するためには，炭素源として酢酸ナトリウム がグルコース+ポリペプトンより有効であった。

\section{廃弿アルコール飲料の微量成分添加高温嫌気性処理}

笠倉 忠夫* 川瀬 三雄* 木田 建次**

* 日本ガイシ株式会社エンジニアリング事業本部 $* *$ 熊本大学工学部応用化学科

〈水質污濁研究 Vol. 14 No. 1(1991） pp.54 60〉

従来，固定床式嫌気性処理分野では高温処理はほとんど取り上げられてこなかったが，筆者らは高濃度溶解 性基質を含む廃水の処理にこの技術を適用し, 高い処理性能の得られることを実証してきた。今回，アルコー ル飲料を原水 $\left(107 \mathrm{kgCOD} \cdot \mathrm{m}^{-3}\right)$ とする廃水処理に，微量成分 $(\mathrm{Fe}, \mathrm{Ni}, \mathrm{Co})$ を添加し多孔性セラミックスを 担体とする固定床式嫌気性処理装置による高温処理を適用することによって，今までにない高い性能 $\left(\mathrm{r}_{\mathrm{s}}=60\right.$ $\mathrm{kgCOD} \cdot \mathrm{m}^{-3} \bullet \mathrm{d}^{-1}$ で $\left.\alpha>0.97\right)$ が得られることを実験的に見出した。

これらの処理において，生物量の変化を考慮しない場合の総括反応速度の基質依存性はいずれも従来の Monodタイプではなく,シグモイド性をもMoser タイプであり,とくに今回の実験結果は強いシグモイド性を 示した。処理条件と処理結果の相関など解明しなければならない課題は残ったが，反応機作を含め嫌気性処理 研究に示唆を与える結果が得られたものと考えている。 